\title{
Selection of Outstanding Lecturers with Simple Additive Weighting Method
}

\author{
Embun Fajar Wati \\ Universitas Bina Sarana Informatika \\ West Jakarta, Indonesian \\ embun.efw@bsi.ac.id
}

\author{
Istikharoh \\ STIKOM Cipta Karya Informatika \\ West Jakarta, Indonesian \\ istikharohiis88@gmail.com
}

\author{
Tuslaela \\ STMIK Nusa Mandiri \\ Central Jakarta, Indonesian \\ tuslaela.tll@nusamandiri.ac.id
}

Submitted: Feb 29, 2020

Accepted: Mar 22, 2020

Published: Apr 1, 2020

\begin{abstract}
Lecturers who excel have the right to be selected and get promotions and awards according to their academic performance. However, Sriwijaya State Buddhist College in Tangerang still uses manual assessment so it requires a lot of time to process the assessment data. Therefore, we need a method of calculation of SAW (Simple Additive Weighting) that can be used as a media for performance appraisal of outstanding lecturers who can facilitate an objective assessment. The SAW calculation aims to assist in the calculation of several criteria in the assessment of the right achieving lecturer. This assessment includes performance appraisals that include commitment, integrity, service orientation, discipline, cooperation, and leadership. In addition to the criteria, the assessment also includes the Employee Performance Target (SKP) assessment. The Employee Performance Target is in the form of a total assessment of lecturer performance. Two criteria, namely performance and SKP will be used as a guide in calculating the selection of outstanding lecturers. Samples were taken as many as 20 lecturers at Sriwijaya State Buddhist College in Tangerang. The simple additive weighting method is effectively used in the selection of outstanding lecturers with an assessment limit of more than 0.88. Of the many candidates, there are three lecturers with adequate performance and SKP, with grades $0.922,0.88,0.94$. So that the highest achieving lecturer with the highest score is 0.94 .
\end{abstract}

Keywords — simple additive weighting; outstanding lecturers; assessment

\section{INTRODUCTION}

One element in the administration of higher education is lecturers. Lecturers are academic staff who are tasked with implementing Tridharma Higher Education, namely teaching, research and community service. Lecturers are entitled to get promotions and awards according to their work assignments and achievements. Promotions and awards will be obtained based on the performance evaluation of lecturers. Lecturer Performance Assessment is important in managing employee performance. This is intended to find out how the quality of performance possessed by the lecturers, because lecturers are an important part in the development of an educational institution. Performance appraisal of lecturer staff has several assessment factors namely education, implementation of education, research, implementation of community service, and supporting academic activities of lecturers. By assessing the performance of lecturers, it can be seen that lecturers are high-achieving and qualified. The award will be given to qualified lecturers as a thank 
you company for the dedication and performance of employees towards the company. And lecturers who are less qualified will be given guidance by educational institutions.

Sriwijaya State Buddhist College in Tangerang is one of the many State Colleges that still uses manual assessment. For lecturers who have the largest number of values, the lecturer is entitled to get an award from the institution. However, the assessment process is still done manually, so it requires a long time to do data processing (Didik Kurniawan, Wamiliana, \& Aditya, 2015). The process of assessing lecturers is still influenced by the element of subjectivity from those who choose, so it cannot support the process. It is probable that there was an inaccuracy in evaluating the performance of each lecturer. And the absence of a computerized teacher performance appraisal system so that the assessment of lecturer performance is inaccurate and will affect the results of lecturer selection to be less accurate and precise. From the description above, it shows that the current system does not provide optimal services for higher education management for lecturers and teaching staff (Rajagukguk \& Limbong, 2017).

Therefore, we need a Decision Support System (DSS) for the assessment of outstanding lecturers to make it easier to calculate the assessment and can be applied on the web, also can be seen on Android that is already installed in the gadget. Android is a type of Operating System (OS) that makes it easy for customers who want to use (Wati, 2018). The way this decision support system works is almost similar to the way an expert system works. So far, conventional computer devices only function as data processing devices, but with an expert system can produce an information (Wati, Siregar, \& Kurniawati, 2018). Similarly, a decision support system that can produce information on the assessment of outstanding lecturers quickly, easily and objectively. The decision support system for the selection of outstanding lecturers uses the Simple Additive Weighting method which is done by creating a paired matrix value for each criterion (Fiqih \& Kusnadi, 2017). The drafting of this DSS is expected to solve the problems faced, and produce decision recommendations that can help the Assessment Team to determine who truly deserves the title of lecturer achievement (Mufizar, 2015).

\section{Literature REVIEW}

\section{A. Relevant Studies}

The decision support system for the selection of outstanding lecturers using the Simple Additive Weighting method in the University of Lampung environment has been successfully built to help solve the problem of determining lecturers to make a pretext by carrying out the selection process objectively based on existing criteria (Didik Kurniawan et al., 2015).

Decision Support System (DSS) for Lecturer Achievement Selection at STMIK Tasikmalaya using the SAW method produces a list of outstanding lecturers with the addition of criteria so as to reduce the level of subjectivity (Mufizar, 2015).

The decision support system for the selection of outstanding lecturers using the SAW Method has been successfully built in the STMIK Budi Darma Medan environment. It can be implemented as an alternative in the objective decision making process (Rajagukguk \& Limbong, 2017).

Decision Support System in the selection of outstanding lecturers at the Djadajat Maritime Academy Jakarta using the method namely Simple Additive Weighting (SAW) method can speed up the process of determining the selection of outstanding lecturers with accurate calculations with the results of research that the outstanding lecturers are given to A13 with 14.4 results (Fiqih \& Kusnadi, 2017).

\section{B. Decision Support System}

According to Holzinger (2011), Decision Support System (DSS) is an intelligent system that includes knowledge-based systems to support decision making activities quickly and accurately (Gustriansyah, 2016). According to Tariq and Rafi (2012), DSS uses data, provides an easy-to-use interface, and allows decision makers to use their own insights (Gustriansyah, 2016). According to Faqih and Irrigation (2014), in other words, a Decision Support System is a computer-based information system that produces various alternative decisions to assist management in dealing with various structured problems using data and models (Windarto, 2017). According to Nofriansyah (2014), Decision support systems (DSS) are usually built to support solutions to a problem or to an opportunity (Badrul, Rusdiansyah, \& Budihartanti, 2019).

\section{Outstanding Lecturer}

In the Law of the Republic of Indonesia Number 14 of 2005 Concerning Teachers and Lecturers, Lecturers with high achievements are lecturers who in the past three years have had useful achievements and can be proud of their origin Universities, and are recognized on a national or international scale (Puspitasari \& Ilmi, 2016).

\section{Simple Additive Weighting (SAW)}

The Simple Additive Weighting (SAW) method is often also known as the weighted sum method. The basic concept of the SAW method is to find a weighted sum of the performance ratings for each 
alternative on all attributes. According to Jayanti (2015), the SAW Method requires the process of normalizing the decision matrix $(\mathrm{X})$ to a scale that can be compared with all existing alternative ratings (Windarto, 2017).

The formula used to normalize is as follows:

$$
\mathrm{R}_{\mathrm{ij}}=\left\{\begin{array}{l}
\frac{X_{i j}}{\operatorname{Max} X_{i j}} \text { jika } j \text { adalah atribut keuntungan (benefit) } \\
\frac{\operatorname{Min} X_{i j}}{X_{i j}} \text { jika } j \text { adalah atribut keuntungan (cost) } X_{i j}
\end{array}\right\}
$$

Figure 1. Normalize Formula

Information:

$\mathrm{Rij}=$ The normalized performance rating from alternative $\mathrm{Ai}$ on attribute $\mathrm{Cj}: \mathrm{i}=1,2, \ldots, \mathrm{m}$ and $\mathrm{j}=$ $1,2, \ldots, \mathrm{n}$

Max Xij = The biggest value of each criterion $\mathrm{i}$

Min Xij = The smallest value of each criterion $\mathrm{i}$

$\mathrm{Xij}=$ attribute value owned by each criterion

Benefit = If the biggest value is the best

Cost $=$ If the smallest value is the best

The preference value for each alternative ( $\mathrm{Vi})$ is given the following formula:

$$
V_{I}=\sum_{J=1}^{n} W_{J} r_{i j}
$$

Figure 2. Preference Formula

Information:

$\mathrm{Vi}=$ Ranking for each alternative

$\mathrm{Wj}=$ Value of ranking weight (of each alternative)

rij = Normalized performance rating value

A greater value of $\mathrm{Vi}$ indicates that the alternative $\mathrm{Ai}$ is preferred.

\section{Proposed Method}

\section{A. Data Collection}

Data collection is done by interviewing the selection of high achieving lecturers and collecting files or documents related to the assessment. After all the data has been collected, the next step is to determine the criteria and minimum value limits for lecturer achievement.

\section{B. Data Analysis}

Data analysis using simple additive weighting (SAW) method. SAW by using the formula that has been explained in the literature review chapter. Based on the current document, the assessment of outstanding lecturers uses two criteria, namely performance and the Employee Performance Target (SKP). Each criterion has a weight of $40 \%$ and $60 \%$. Based on the specified weight, the assessment of lecturer achievement has a value limit that is more than 0.88 .

\section{RESUlt AND DiscusSion}

\section{A. Calculation of SAW}

The study was conducted at Sriwijaya State Buddhist High School in Tangerang with stages beginning with data collection by interviewing the assessment team and collecting documents in the form of a list of lecturers' values in which there were various performance criteria and the amount of their grades. The overall assessment is the lecturers who teach at Sriwijaya State Buddhist College. Samples of lecturers taken were 20 people, with the criteria of performance and SKP. Performance includes several sub-criteria, namely commitment, integrity, service orientation, discipline, cooperation, and leadership. Whereas meant by SKP is employee performance target.

Because performance appraisal there are six types of assessment (commitment, integrity, service orientation, discipline, cooperation and leadership). The six types of performance will be calculated on average then will be divided by the maximum value of performance.

The next step is normalization using a predetermined formula. After that, calculate the preferences of each criterion using the preference calculation formula. A lecturer with a preference value of more than 0.88 is an outstanding lecturer. The final results of calculations using the SAW method can be seen in the following figure 3 .

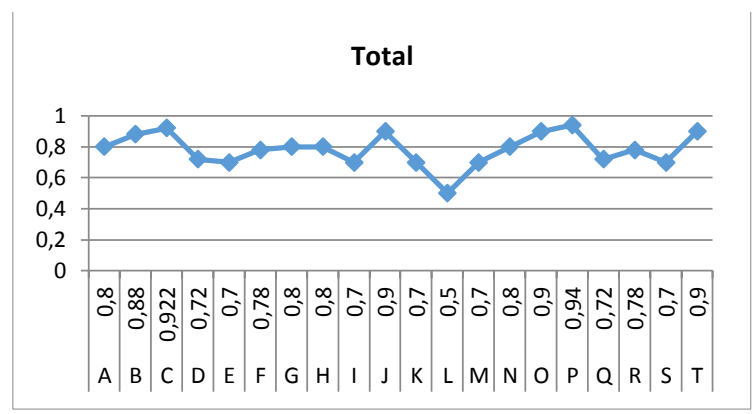

Figure 3. Assessment Results Data

Example calculation 3 The sample with the largest value will be explained below.

Table 1. Amount of Values

\begin{tabular}{|c|c|c|}
\hline Lecture & $\mathrm{C} 1$ & $\mathrm{C} 2$ \\
\hline $\mathrm{C}$ & 79,33 & 84,34 \\
\hline $\mathrm{B}$ & 76,33 & 80 \\
\hline $\mathrm{P}$ & 77,5 & 88 \\
\hline
\end{tabular}

Table 2. Determination of Average Criteria 


\begin{tabular}{|c|c|c|c|c|c|c|c|c|}
\hline Lect & Cm & I & S & D & Cp & L & Amount & $\begin{array}{c}\text { Rata- } \\
\text { Rata }\end{array}$ \\
\hline C & 91 & 71 & 79 & 78 & 79 & 78 & 476 & 79,33 \\
\hline B & 70 & 89 & 90 & 78 & 67 & 64 & 458 & 76,33 \\
\hline P & 77 & 89 & 76 & 78 & 77 & 68 & 465 & 77,5 \\
\hline
\end{tabular}

Information :

$\mathrm{C} 1=$ Performance

$\mathrm{C} 2=\mathrm{SKP}$

Lect $=$ Lecture

$\mathrm{Cm}=$ Commitment

$\mathrm{I}=$ Integrity

$\mathrm{S}=$ Service Orientation

$\mathrm{D}=$ Discipline

$\mathrm{Cp}=$ Cooperation

$\mathrm{L}=$ Leadership

Table 2 shows the six types of performance will be calculated on average. Calculation of the SAW formula starts with normalization for all criteria.

- Performance Normalization
$\mathrm{C}: \frac{79,33}{91}=0,871$
B : $\frac{76,33}{91}=0,838$
$\mathrm{P}: \frac{77,5}{91}=0,851$

- SKP Normalization
C : $\frac{84,34}{88}=0,958$
B : $\frac{80}{88}=0,909$
$\mathrm{P}: \frac{88}{88}=1$

Table 3. Normalization Results

\begin{tabular}{|c|c|c|}
\hline Lecture & $\mathrm{C} 1$ & $\mathrm{C} 2$ \\
\hline $\mathrm{C}$ & 0,871 & 0,958 \\
\hline $\mathrm{B}$ & 0,838 & 0,909 \\
\hline $\mathrm{P}$ & 0,851 & 1 \\
\hline
\end{tabular}

After the normalization results are obtained, the next step is to calculate using the preference formula.

Weight of each criterion :

$\mathrm{C} 1=0,4(40 \%)$ and $\mathrm{C} 2=0,6(60 \%)$

- Performance Preference

$$
\begin{aligned}
& \text { C : } 0,4 \times 0,871=0,348 \\
& \text { B : } 0,4 \times 0,838=0,335 \\
& \text { P : } 0,4 \times 0,851=0,340
\end{aligned}
$$

- SKP Preference

$$
\begin{aligned}
& \text { C : } 0,6 \times 0,958=0,574 \\
& \text { B : } 0,6 \times 0,909=0,545 \\
& P: 0,6 \times 1=0,6
\end{aligned}
$$

Table 4. Preference Calculation Results

\begin{tabular}{|c|c|c|c|}
\hline Lecture & $\mathrm{C} 1$ & $\mathrm{C} 2$ & Results \\
\hline $\mathrm{C}$ & 0,348 & 0,574 & 0,922 \\
\hline $\mathrm{B}$ & 0,335 & 0,545 & 0,88 \\
\hline $\mathrm{P}$ & 0,340 & 0,6 & 0,94 \\
\hline
\end{tabular}

The final calculation result is using the preference formula, it can be concluded that the highest value is 0.94 achieved by lecturer $P$.

\section{B. Interface and Class Diagram Produced}

The interface generated from the achievement lecturer assessment system using the Simple Additive Weighting (SAW) method can be seen in the following pictures:

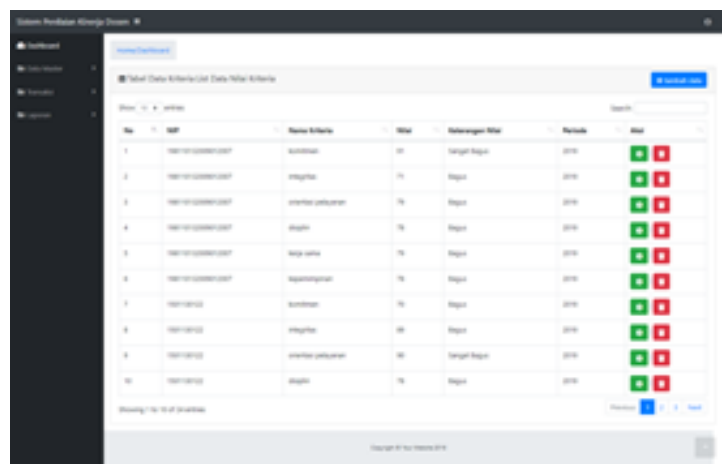

Figure 4. Performance Interface

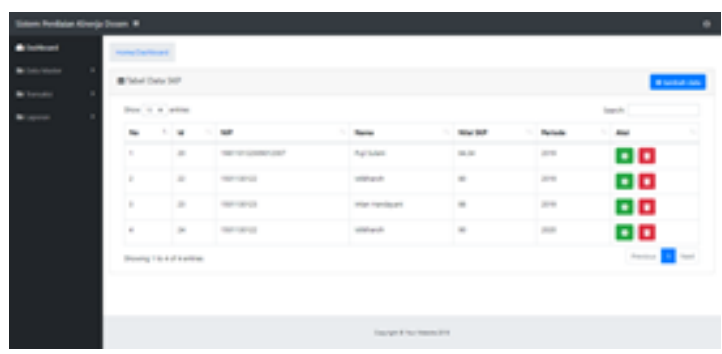

Figure 5. SKP Interface 


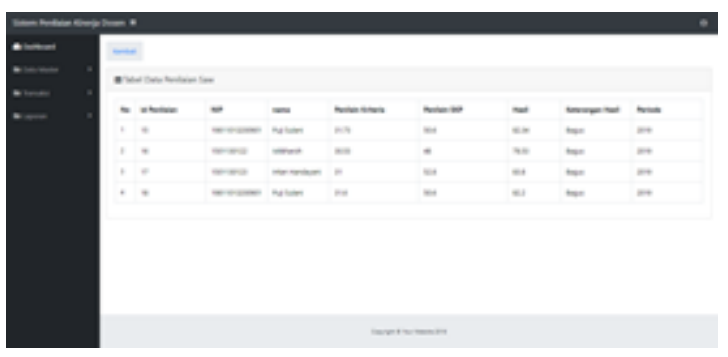

Figure 6. Assessment Data Interface

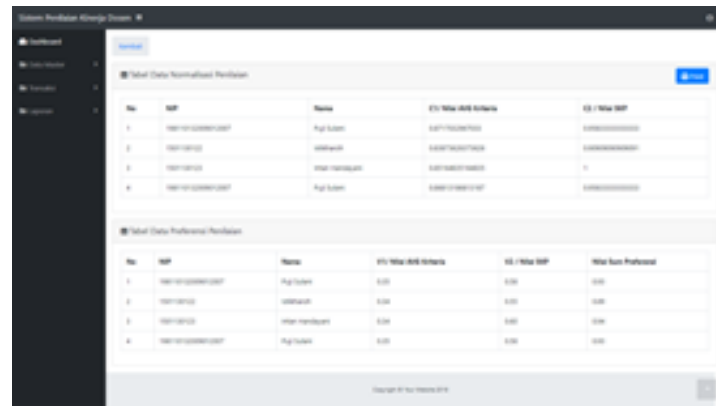

Figure 7. Normalization and Preference Results Interface

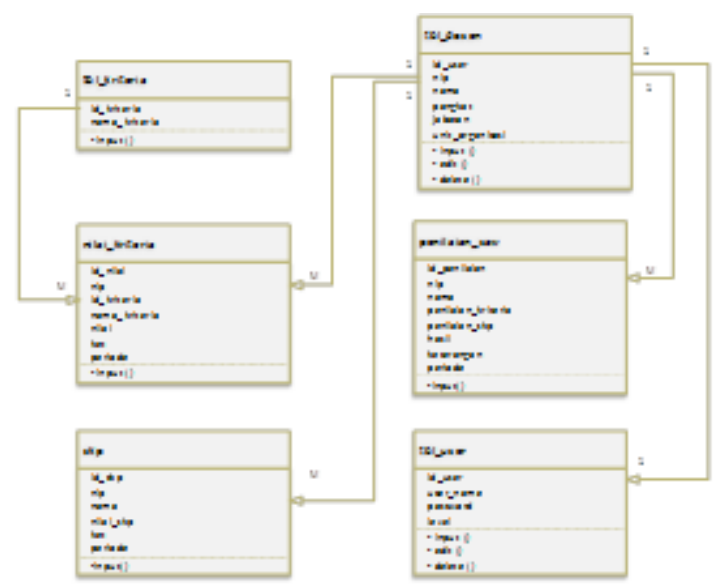

Figure 8. Class Diagram

The interface in figure 4-7 illustrates a web-based application that can be opened in an installed browser. While the entities and attributes created in the database can be seen in figure 8 .

\section{Conclusion And Suggestion}

Assessment of outstanding lecturers with two criteria, namely performance and SKP can be used as a reference because it is objective with the final value that can be known and given a ranking. Value is also certain with complete data from these two criteria. One criterion is that performance can represent many assessments because there are 6 factors that influence it, namely commitment, integrity, service orientation, discipline, cooperation, and leadership. Six factors are searched for the average value then calculated using SAW to produce a final grade of 20 lecturers with the lowest value of 0.7 and the highest value of 0.94 .

\section{ACKNOWLEDGMENT}

The author would like to thank all those who have helped in the completion of this scientific article, especially family, friends, and also the entire SINKRON crew.

\section{REFERENCES}

Badrul, M., Rusdiansyah, \& Budihartanti, C. (2019). Application of Simple Additive Weighting Method for Determination of Toddler Nutrition Status. Sinkron, 4(1), 19-24.

Didik Kurniawan, Wamiliana, \& Aditya, R. C. (2015). Sistem Pendukung Keputusan Pemilihan Dosen Berprestasi Menggunakan Metode Simple Additive Weighting di Lingkungan Universitas Lampung. Komputasi, 3(2), 90-98.

Fiqih, M., \& Kusnadi, Y. (2017). Sistem Pendukung Keputusan Pemilihan Dosen Berprestasi Dengan Metode Simple Additive Weighting. INFORMATION SYSTEM FOR EDUCATORS AND PROFESSIONALS, 2(1), 41-50.

Gustriansyah, R. (2016). SISTEM PENDUKUNG KEPUTUSAN PEMILIHAN DOSEN BERPRESTASI DENGAN METODE ANP DAN TOPSIS. In Seminar Nasional Teknologi Informasi dan Komunikasi (SENTIKA) (pp. 3340). Yogyakarta.

Mufizar, T. (2015). Sistem Pendukung Keputusan Pemilihan Dosen Berprestasi Di STMIK Tasikmalaya Menggunakan Metode Simple Additive Weighting (SAW). CSRID, 7(3), 155166.

Puspitasari, W. D., \& Ilmi, D. K. (2016). SISTEM PENDUKUNG KEPUTUSAN PEMILIHAN DOSEN BERPRESTASI MENGGUNAKAN METODE ANALYTICAL HIERARCHY PROCESS (AHP). Antivirus, 10(2), 56-68.

Rajagukguk, D. M., \& Limbong, R. (2017). Implementasi Metode Simple Additive Weighting (SAW) Pada Sistem Pendukung Keputusan Pemilihan Dosen Berprestasi. MEANS (Media Informasi Analisa Dan Sistem), 2(2), 124-133.

Wati, E. F. (2018). APLIKASI SISTEM LAYANAN PESAN ANTAR MAKANAN BERBASIS ANDROID PADA KEDAI AYAM REMUK, TANGERANG. JISAMAR (Journal of Information System, Applied, Management, 
Accounting and Research), 2(2), 1-12.

Wati, E. F., Siregar, M. H., \& Kurniawati, N. I. (2018). Expert System Diagnosa Penyakit Paru pada Anak dengan Metode Forward Chaining. JISICOM, 2, 10-15.
Windarto, A. P. (2017). IMPLEMENTASI METODE TOPSIS DAN SAW DALAM MEMBERIKAN REWARD PELANGGAN. Kumpulan JurnaL Ilmu Komputer (KLIK), 4(1), 88-101. 